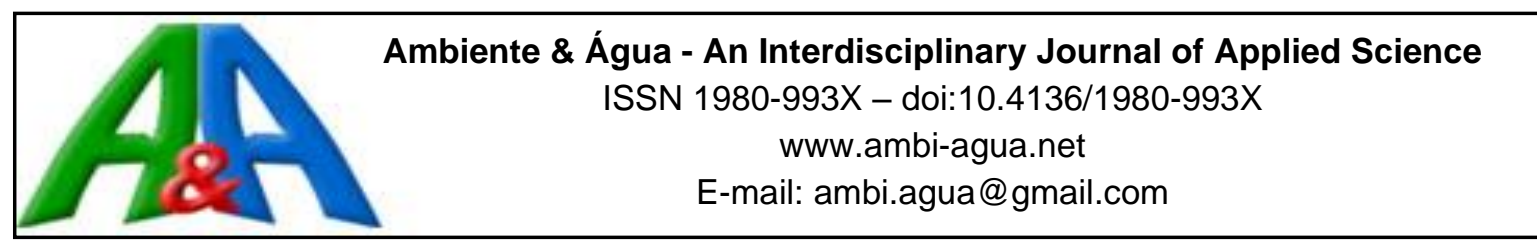

\title{
Coliform removal in a constructed wetland system used in post-swine effluent treatment
}

\author{
ARTICLES doi:10.4136/ambi-agua.2402
}

Received: 12 Apr. 2019; Accepted: 19 Jul. 2019

\begin{abstract}
Fabiana de Amorim ${ }^{1}$; Jaíza Ribeiro Mota e Silva ${ }^{1^{*}(\mathbb{D}}$; Ronaldo Fia ${ }^{1}$; Luiz Fernando Coutinho de Oliveira ${ }^{1}$; Cláudio Milton Montenegro Campos ${ }^{1}$ (iD

${ }^{1}$ Departamento de Recursos Hídricos e Saneamento (DRS), Universidade Federal de Lavras (UFLA), Câmpus Universitário, Caixa Postal 3037, CEP 37200-000, Lavras, MG, Brazil.

E-mail: fabianadeamorim@yahoo.com.br, ronaldofia@ufla.br, coutinho@ufla.br, cmmcampos@gmail.com *Corresponding author. E-mail: jaizamota@hotmail.com
\end{abstract}

\begin{abstract}
This study evaluated the efficiency of a constructed wetland system (CWS) in removing total coliforms (TC) and thermotolerant coliforms (ThC) of swine wastewater, as a complementary treatment to an anaerobic system. At Stage 1, the experimental system was combined using a vertical flow constructed wetland system (VFCWS) cultivated with Tifton 85 grass in series with a horizontal subsurface flow constructed wetland system (HFCWS1) cultivated with Taboa. In HFCWS1, the hydraulic detention times (HDT) were 4.7, 3.1 and 2.3 days and the surface application rates (SAR) were 294, 319 and $397 \mathrm{~kg} \mathrm{ha}^{-1} \mathrm{~d}^{-1}$ of COD, in Phases I, II and III, respectively. At Stage 2, the experimental system was combined using a horizontal subsurface flow constructed wetland system (HFCWS2) cultivated with Tifton 85 grass, HDT were 6.1, 2.0 and 0.5 days and the SAR were 850,656 and $6.34 \mathrm{~kg} \mathrm{ha}^{-1} \mathrm{~d}^{-1}$ of COD, in Phases I, II and III, respectively. In Stage 1, it was verified that the VFCWS was more efficient in coliform removal when compared to HFCWS1. When only HFCWS were compared, coliform removal in Stage 1 was between 1 and 2 log units in HFCWS1. In the stage 2, the HFCWS2 was more limited, with the highest removal efficiencies during Phase I of 1.6 and $0.8 \mathrm{log}$ units for $\mathrm{TC}$ and $\mathrm{ThC}$, respectively. In general, the association resulted in efficiencies that ranged from 96.4 to $99.0 \%$ for TC, 94.2 and $97.6 \%$ for ThC, equivalent to the average removal of 1.2 to $2 \log$ units, considered satisfactory.
\end{abstract}

Keywords: agricultural reuse, Cynodon spp., sanitary risk, tertiary treatment, Typha sp.

\section{Remoção de coliformes em sistema alagado construído utilizado no pós- tratamento de efluentes de suinocultura}

\section{RESUMO}

O objetivo deste estudo foi avaliar o desempenho de um sistema alagado construído (CWS) na remoção de coliformes totais (TC) e coliformes termotolerantes (ThC) de água residuária da suinocultura, como tratamento complementar a um sistema anaeróbio. Na etapa 1 , o sistema experimental foi composto por um sistema alagado construído de escoamento vertical (VFCWS) cultivado com capim Tifton 85 em série com um sistema alagado construído de escoamento subsuperficial horizontal (HFCWS1) cultivado com Taboa. No HFCWS1 os 
tempos de detenção hidráulica foram de 4,7; 3,1 e 2,3 dias e as taxas de aplicação superficial foram 294, 319 e $397 \mathrm{~kg} \mathrm{ha}^{-1} \mathrm{~d}^{-1}$ de DQO, nas fases I, II e III, respectivamente. Na etapa 2, o sistema experimental foi composto por um sistema alagado construído de escoamento subsuperficial horizontal (HFCWS2) cultivado com capim Tifton 85, os tempos de detenção hidráulica foram 6,$1 ; 2,0$ e $0,5 \mathrm{~d}$ e as taxas de aplicação superficial foram 850, 656 e $6,34 \mathrm{~kg} \mathrm{ha}^{-1} \mathrm{~d}^{-1}$ de DQO, nas fases I, II e III, respectivamente. Na etapa 1, verificou-se que o VFCWS foi mais eficiente na remoção de coliformes quando comparado ao HFCWS1. Quando comparados apenas os HFCWS, verificou-se que a remoção de coliformes na etapa 1 variou de 1 a 2 unidades log no HFCWS1. Na etapa 2, o HFCWS2 mostrou-se mais limitado, apresentando maiores eficiências de remoção na fase I, de 1,6 a 0,8 unidades $\log$ para TC e ThC, respectivamente. Em geral, a associação resultou em eficiências que variaram de 96,4 a 99,0\% para TC e de 94,2 e 97,6\% para ThC, equivalente a remoção média de 1,2 a 2 unidades $\log$, considerada satisfatória.

Palavras-chave: Cynodon spp., reúso agrícola, risco sanitário, tratamento terciário, Typha sp.

\section{INTRODUCTION}

Agricultural business is the largest consumer of water in its various stages of production, and the scarcity of water resources in quantity and quality warns of the necessity to improve processes of treatment and reuse of water. It is estimated that $50 \%$ of the world's population will live in regions with water shortages by 2025 , which highlights the importance of appropriate treatment and management of water (WHO, 2015).

The biggest challenge to the use of wastewater in agriculture is to propose techniques of treatment and management that reduce the possibility of crop contamination by pathogenic microorganisms and heavy metals.

Wastewater from pig farming has some of its components (organic matter, nitrogen, phosphorus, copper, etc.) in concentrations that are sufficiently high to constitute a risk of ecological imbalance when disposed inappropriately in watercourses. However, once it is well monitored, the use of this type of wastewater in agricultural arises as an alternative to its disposal, with the benefit of recycling nutrients for crops (Cavalett et al., 2006).

In order to do that, the fertigation of pastures and fodder has been recommended, according to Matos (2007), as an alternative for the use of these effluents due to the rapid growth and the formation of large root mass of these cultures. Therefore, it must consider the desired levels of purification for reuse or disposal final destination, in accordance with the established conditions for the quality of water bodies receptors (Conama, 2011) or further uses, defining from these, respective processes and treatment systems.

Standards are based on the values established in the guidelines of the World Health Organization (WHO, 2006), and also in resolution $\mathrm{N}^{\circ} .430$ of the National Council of Environment (Conama, 2011), which define the limits of thermotolerant coliforms by $2 \times 10^{2}$, $\mathrm{x} 1 \times 10^{3}$ and $4 \times 10^{3}$ MPN $100 \mathrm{~mL}^{-1}$ in bodies of fresh water of Classes 1, 2 and 3, respectively, which can be captured water for irrigation of different crops.

Wastewater from pig farming contains large amount of coliforms, and their disposal in the environment without proper management puts the sustainability and the expansion of pig farming at risk.

According to Fia et al. (2010), the use of built reactors cultivated with plant species, also called constructed wetlands systems (CWSs), as post-treatment of these effluents allows to obtain a better quality effluent that meets current environmental legislation for disposal in watercourses.

The CWSs are artificial systems consisting of ponds or shallow vegetative channels used 
for the treatment of wastewater rich in organic material susceptible to biodegradation, enabling the improvement of landscape aesthetics and increasing habitat for wildlife (Kadlec and Wallace, 2008). The CWSs have long been used due to their simple technology, moderate installation cost, reduced energy consumption, easy operation and maintenance (Brasil et al., 2007).

In the CWSs, the removal of pathogen microorganisms occurs through a combination of physical, chemical and biological processes. Also through mechanisms of sedimentation, filtration, ultraviolet radiation, oxidation, adsorption to organic matter, exposure to biocides excreted by macrophytes, predation and natural decay (Lin et al., 2005; Kadlec and Wallace, 2008; Morató et al., 2014; Zurita and Carreón-Álvarez, 2014; Rachmadi et al., 2016; Wu et al 2016; Machado et al., 2017).

Plant species being cultured in CWSs, Tifton 85 grass (Cynodon sp.), proved to be suitable due to its high productivity and nutrient extraction capacity reached due to the fast recovery after cutting, with good coverage of the soil and preventing the development of invasive species (Queiroz et al., 2004). Matos et al. (2009) verified satisfactory removal of ThC (average values measured at the influent and effluent were, respectively: $1.70 \times 10^{7}$ and $7.93 \times 10^{5} \mathrm{MPN}$ $100 \mathrm{~mL}^{-1}$ ) in CWSs treating swine wastewater pretreated in organic filters. In addition, Tifton 85 grass can tolerate wide temperature variations and shows interesting nutritional characteristics for livestock (Sanches et al., 2016; Pereira et al., 2012; Matos et al., 2013; Amorim et al., 2015a).

Thus, this work aimed to evaluate the removal of total coliforms (TC) and thermotolerant coliforms (ThC) of swine wastewater treated in a constructed wetland system (CWS) as a complementary treatment to the anaerobic system, and to verify the contamination of the aerial part of the plant grown in the CWS.

\section{MATERIAL AND METHODS}

The experiment was conducted in the area of wastewater treatment in the Lavras Federal University (UFLA) Department of Animal Science (DZO), under the responsibility of the UFLA Engineering Department (DEG), Minas Gerais, Brazil, with geographic coordinates $21^{\circ} 13^{\prime} 55^{\prime \prime}$ South latitude and $44^{\circ} 58^{\prime} 12^{\prime \prime}$ West longitude, and the average elevation of $895 \mathrm{~m}$.

The system was installed in a protected environment (greenhouse), with a plastic structure of transparent polyethylene of $150 \mathrm{~mm}$. The structure dimensions were: $12 \mathrm{~m}$ long by $10 \mathrm{~m}$ wide, $3 \mathrm{~m}$ ceiling height and $1.5 \mathrm{~m}$ arches. On the sides of the greenhouse were installed black mesh shading (Sombrite ${ }^{8} 50 \%$ ). The experiment was conducted in two stages.

\subsection{Stage 1}

The swine wastewater was from the DZO Pig Sector. The swine wastewater treatment is composed of a static sieve pretreatment and primary treatment compound of a decanter, a secondary treatment compound Anaerobic Baffled Reactor (ABR) followed by UASB reactor (Pereira et al., 2012). In this way, the swine wastewater used in this stage was the anaerobic treatment system effluent.

The experimental arrangement was composed of two constructed wetlands systems. A vertical flow constructed wetland system (VFCWS) and a horizontal subsurface flow construct system (HFCWS1) (Figure 1).

The VFCWS consisted of fiberglass tanks, with total volume of $100 \mathrm{~L}$, with $0.54 \mathrm{~m}$ tall and $0.86 \mathrm{~m}$ in diameter, filled with gravel (diameter D-60 $=7.0 \mathrm{~mm}$ and initial porosity of $0.494 \mathrm{~m}^{3} \mathrm{~m}^{-3}$ ). 


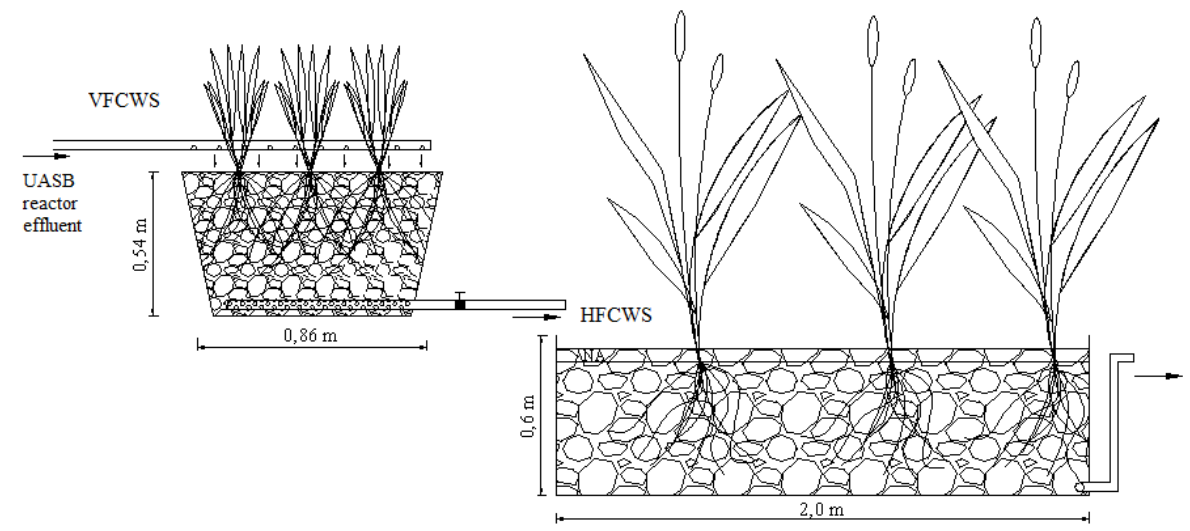

Figure 1. Schematic diagram of vertical flow constructed wetland system (VFCWS) and horizontal subsurface flow constructed wetland system (HFCWS1).

In HFCWS1, 4, chicanes were equally spaced installed along the structure in order to improve the distribution of the flow inside the unit. The dimensions of HFCWS1 were $2.0 \mathrm{~m}$ long by $0.5 \mathrm{~m}$ wide and $0.70 \mathrm{~m}$ in height. The HFCWS1 was filled with same the gravel, as a support, up to the height of $0.55 \mathrm{~m}$, comprising a porosity of $0.494 \mathrm{~m}^{3} \mathrm{~m}^{-3}$. The disposal of the flow occurred at $0.05 \mathrm{~m}$ below the surface, totaling a volume of $237 \mathrm{~L}$, more details can be obtained from the work of Fia et al. (2014).

The VFCWS was cultivated with Tifton 85 grass (Cynodon spp.) from DZO Forage Sector. The density of planting was 20 seedlings per $\mathrm{m}^{2}$. The specie cultivated in the HFCWS was "Taboa" (Typha sp.). The seedlings were obtained in natural wetlands in the UFLA Fish Farming Sector. The density of planting was 14 seedlings per $\mathrm{m}^{2}$.

This stage was composed of three phases (September 2011 to February 2012). Phase 1 was carried out to adapt the systems to the swine wastewater, it lasted 80 days. In Phase 2 and Phase 3 , the surface application rates were increased, with a duration of 60 days each.

The differentiation in the surface application rates was made through the variation of the VFCWS affluent. VFCWS feeds were made through a solenoid metering pump and hoses of PVC, which pumped from a container that held swine wastewater. The pumped wastewater came from an existing effluent originated from a previous treatment system (ABR and UASB reactors and decanter). The HFCWS1 was conducted by gravity from the VFCWS. The operational characteristics of monitoring were obtained from the affluent COD concentration multiplied by the input flow and dividing by the surface area of the VFCWS and HFCWS 1. The hydraulic retention time values were obtained by dividing the flow by HFCWS1 volume. The operational characteristics of wetlands systems are presented in Table 1.

Table 1. Operational average characteristics observed in vertical flow constructed wetland system (VFCWS) and horizontal subsurface flow constructed wetland system (HFCWS) at the phases of operation of the treatment system in Stage 1.

\begin{tabular}{cccccccccc}
\hline \multirow{2}{*}{ System } & \multicolumn{3}{c}{ Phase I $(80 \mathrm{~d})$} & \multicolumn{3}{c}{ Phase II $(60 \mathrm{~d})$} & \multicolumn{3}{c}{ Phase III $(60 \mathrm{~d})$} \\
\cline { 2 - 10 } & $\mathrm{HDT}^{51}$ & $\mathrm{Q}^{51}$ & $\mathrm{SAR}^{13}$ & $\mathrm{HDT}^{29}$ & $\mathrm{Q}^{29}$ & $\mathrm{SAR}^{9}$ & $\mathrm{HDT}^{24}$ & $\mathrm{Q}^{24}$ & $\mathrm{SAR}^{8}$ \\
\hline VFCWS & - & 0.064 & 763 & - & 0.095 & 828 & - & 0.129 & 1,032 \\
HFCWS & 4.7 & - & 294 & 3.1 & - & 319 & 2.3 & - & 397 \\
\hline
\end{tabular}

Legend: HDT - hydraulic detention time (days); Q - flow $\left(\mathrm{m}^{3} \mathrm{~d}^{-1}\right)$; SAR - surface application rate $\left(\mathrm{kg} \mathrm{ha}^{-1} \mathrm{~d}^{-1}\right.$ of $\left.\mathrm{COD}\right)$; superscript the number of sampling considered in the calculation of the average. 


\subsection{Stage 2}

The constructive characteristics were kept identical to HFCWS1 (Stage 1). However, the HFCWS2 was cultivated with Tifton 85 grass (Cynodon spp.). Parts of the stem of the plant, from DZO Forage Sector, were planted in plastic containers, containing sand and a mixture of water and swine wastewater in proportion of 1:1 (v/v), for the development of the root system. After 15 days, it was planted in the HFCWS2. This procedure was performed during 40 days before placing the swine wastewater in the treatment system, using the density of 25 plants per $\mathrm{m}^{2}$. Every 2 days, in this initial stage, water and swine wastewater in proportion of $1: 1(\mathrm{v} / \mathrm{v})$ was applied, according to the CWS evapotranspiration.

The swine wastewater applied in HFCWS2 was also from an anaerobic system (Amorim et al., 2015b). The effluent was conducted by continuous-flow pipe, with the aid of a metering pump for UASB and subsequently by gravity to the CWS.

This stage had three phases during the monitoring (February to July 2014), being the duration periods determined by forage cutting, which were carried out when the first inflorescence happened. This fact occurred 60 days after the beginning of the monitoring system, 32 days after the first cut of the plants and 50 days after the second cutting of plants, coinciding with the completion of Phases I, II and III, respectively. From the affluent concentration of COD, the flow, and the surface area of the HFCWS2, were obtained the operational characteristics of monitoring. The hydraulic detention time values were obtained by dividing the flow by the HFCWS2 volume. The operational characteristics of HFCWS 2 are presented in Table 2 .

Table 2. Operational characteristics observed in horizontal subsurface flow constructed wetland system (HFCWS2) at the phases of operation of the treatment system in Stage 2.

\begin{tabular}{cccc}
\hline Variables & Phase I (47 d) & Phase II (32 d) & Phase III (52 d) \\
\hline HDT & $6.1^{(20)}$ & $2.0^{(20)}$ & $0.5^{(18)}$ \\
Q & 0.0439 & 0.1175 & 0.4766 \\
SAR & $850^{(18)}$ & $656^{(9)}$ & $6,335^{(14)}$ \\
\hline
\end{tabular}

Legend: HDT - hydraulic detention time (days); Q - flow $\left(\mathrm{m}^{3} \mathrm{~d}^{-1}\right)$; SAR - surface application rate $\left(\mathrm{kg} \mathrm{ha}^{-1} \mathrm{~d}^{-1}\right.$ of COD); superscript the number of sampling considered in the calculation of the average.

At the end of each phase, which coincided with the emergence of the first stems, the grass with 5 to $7 \mathrm{~cm}$ height above the middle support was mowed. Fresh biomass collected, $10 \mathrm{~g}$ every $0.40 \mathrm{~m}$ along the CWS, was placed in a plastic bag with $90 \mathrm{~mL}$ of peptone $(0.1 \%)$ and taken to 3,500 rpm in a Stomacher Homogenizer for 3 minutes for immediate microbiological analysis. Therefore, the quantification of total coliforms was carried out using the method of multiple tubes (APHA et al., 2005). Three repetitions were made and the assessment was done in triplicate for each sampling.

In two phases, the quantification of coliforms presented in the influent was held weekly, also by the method of multiple tubes (APHA et al., 2005). The instantaneous air and liquid temperature in treatment was measured daily, at $07 \mathrm{~h} 00 \mathrm{AM}$ by a thermo-hygrometer.

\section{RESULTS AND DISCUSSION}

During the monitoring system, the temperature in the greenhouse ranged from $14.9^{\circ} \mathrm{C}$ to $36.5^{\circ} \mathrm{C}$ in the first stage, and from $8.0^{\circ} \mathrm{C}$ to $49.0^{\circ} \mathrm{C}$ in the second stage. However, swine wastewater in treatment showed lower temperature variation, with average values of $23.8^{\circ} \mathrm{C}$, $23.5^{\circ} \mathrm{C}$ and $23.8^{\circ} \mathrm{C} ; 26.5^{\circ} \mathrm{C}, 20.8^{\circ} \mathrm{C}$ and $18.0^{\circ} \mathrm{C}$, in Phases I, II and III, of Stages 1 and 2, 
respectively. Temperature is extremely important in biological treatment processes, being related to the speed of biochemical reactions and enzymes of microorganisms responsible for pollutant removal, reducing the temperature values along the phases may interfere in the removal efficiency of substrates and microorganisms present in the swine wastewater (Olson $e t$ al., 2004). Winward et al. (2008) reported that seasonal changes in temperature could strongly influence the coliform removal in CWS, in which was a positive correlation between the removal of bacteria and the temperature rise.

In this way, the reduction of the temperature of the liquid, especially in the Phase III of Stage 2, may have contributed to a minor reduction in the number of indicators of fecal contamination, compared to previous phases. The constants of the first order for decay of $E$. coli in CWS obtained by Boutilier et al. (2009) were $0.09 \mathrm{~d}^{-1}$ at $7.6^{\circ} \mathrm{C}$ and $0.18 \mathrm{~d}^{-1}$ at $22.8^{\circ} \mathrm{C}$.

The amount of TC and influent concentration to the experimental units varied according to the composition of the wastewater, which was dependent on the cleaning procedure and handling of swine breeding facilities (Figures 2 and 3). This variation reflected in effluent concentrations of the systems, as the secondary treatment units, such as the constructed wetlands systems feature, are less efficient to removal these microorganisms. Von Sperling (2005) reports that anaerobic reactors and CWS are able to remove between one and three and one and four log units of resolutions, respectively.
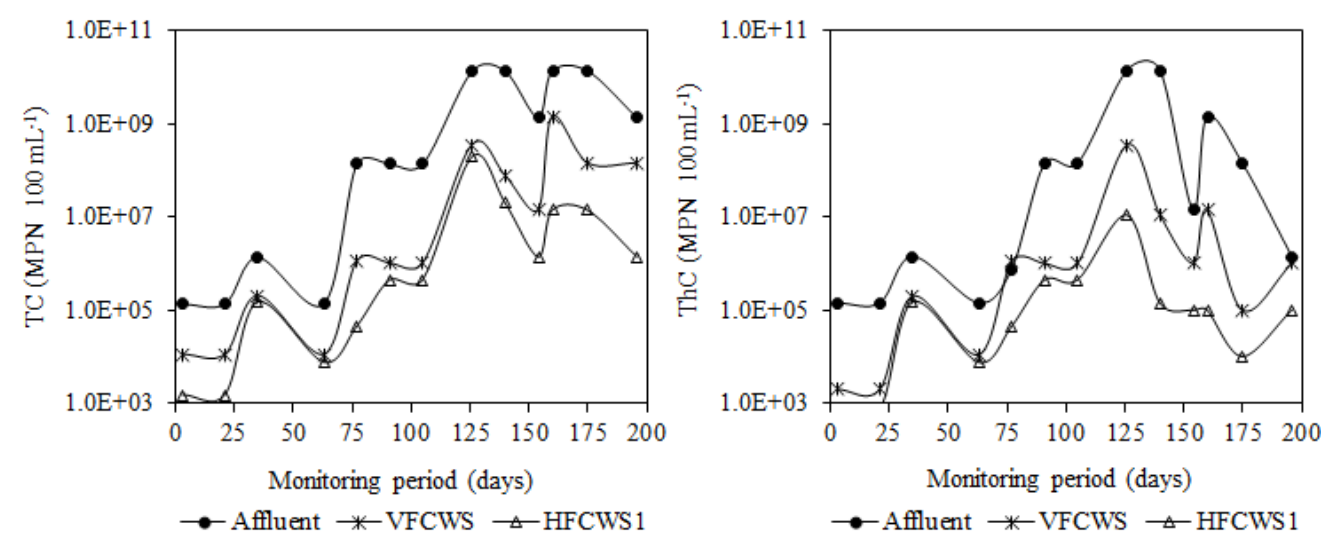

Figure 2. Variation in most probable number of total coliforms (TC) and thermotolerant coliforms (ThC) in the affluent and effluent from vertical flow constructed wetland system (VFCWS) and horizontal subsurface flow constructed wetland system (HFCWS1) at the phases of operation of the treatment system in Stage 1 .
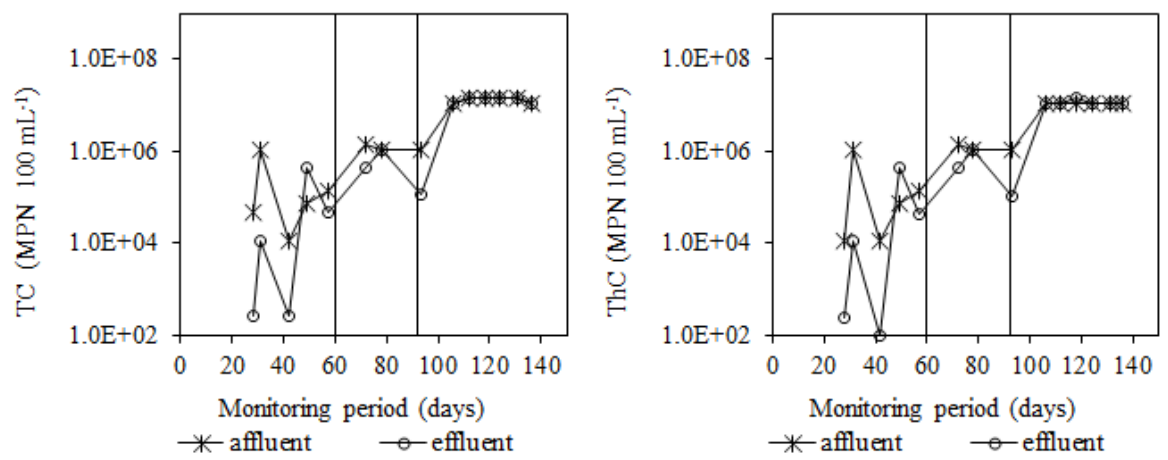

Figure 3. Variation in most probable number of total coliforms (TC) and thermotolerant coliforms $(\mathrm{ThC})$ in the affluent and effluent of horizontal subsurface flow constructed wetland system (HFCWS2) at the phases of operation of the treatment system in Stage 2. Vertical lines indicate the changes in the monitoring phase. 
In general, in Stage 1, it was found that the VFCWS was more efficient in the removal of coliforms compared to HFCWS1. This fact is related to the operation manner of the systems. The VFCWS was not kept saturated with effluent, increasing the possibility of removing the microorganisms by humidity reducing (Kadam et al., 2008; Tunçsiper et al., 2012). Abou-Elela and Hellal (2012) achieved in domestic sewage treated with VFCWS 1,25x10 3 MPN $100 \mathrm{~mL}^{-1}$, which resulted in an efficiency of removal between $94.0 \%$ and $99.9 \%$. Authors attributed the best efficiencies observed, when compared to literature, to the highest rate of oxygenation in vertical systems, in addition to the highest temperature observed $\left(25\right.$ to $\left.30^{\circ} \mathrm{C}\right)$ during the experiment. Aerobic conditions reduce the length of survival for pathogens in constructed wetlands systems.

Increasing the organic load and the consequent reduction in the hydraulic detention time, in different phases of the two stages, resulted that the effluent concentrations of the VFCWS, HFCWS1 and HFCWS2 also followed an increase in the number of microorganisms to the system. This fact was also verified by Hill and Sobsey (2001) in constructed wetland system.

In Stage 1, it was verified that, independent of the concentration of coliforms and the applied, there was a higher coliform removal, compared to Stage 2 (Table 3). Although in Stage 1 higher values of coliforms were verified in the influent, mainly in the third stage, it seems that the hydraulic detention time and organic concentration are the most affected factors in coliform removal efficiency in constructed wetlands systems.

Table 3. Average removal of total coliforms (TC) and thermotolerant coliforms (ThC), in \%, in vertical flow constructed wetland system (VFCWS) and horizontal subsurface flow constructed wetland system (HFCWS1) in Stage 1, and horizontal subsurface flow constructed wetland system (HFCWS2) in Stage 2 at the phases of operation of the treatment system.

\begin{tabular}{cccccccc}
\hline \multirow{2}{*}{ Stage } & \multirow{3}{*}{ Phase } & \multicolumn{3}{c}{ TC } & \multicolumn{2}{c}{ ThC } \\
\cline { 3 - 8 } & & VFCWS & HFCWS1/HFCWS2 & Total & VFCWS & HFCWS1/HFCWS2 & Total \\
\hline & I & $92.2(2.0)$ & $65.1(1.8)$ & $96.3(2.0)$ & $75.0(1.6)$ & $55.5(1.7)$ & $95.4(2.0)$ \\
1 & II & $98.9(2.0)$ & $56.6(1.7)$ & $99.5(2.0)$ & $99.0(2.0)$ & $76.4(1.9)$ & $99.8(2.0)$ \\
& III & $94.5(2.0)$ & $94.5(2.0)$ & $99.9(2.0)$ & $80.1(1.9)$ & $92.3(2.0)$ & $98.1(2.0)$ \\
\hline \multirow{2}{*}{2} & I & - & $73.0(1.6)$ & - & - & $73.0(0.8)$ & - \\
& II & - & $53.0(0.7)$ & - & - & $53.0(0.0)$ & - \\
\hline
\end{tabular}

The values in parentheses correspond to the log units removed.

When only the HFCWS were compared, it was verified that removal of coliform in the first phase ranged from 1 to $2 \log$ units in HFCWS1. In Stage 2, the HFCWS2 showed to be more limited, being the highest removal efficiencies in Phase I, $1.6 \log$ units for TC and $0.8 \log$ units for ThC. The smallest removal in Phases II and III may be related to an increase in the load rates and, consequently, to the reduction of hydraulic detention time, besides the lowest temperatures.

Highest values of hydraulic detention time increase the exposure of bacteria to removal processes such as sedimentation, adsorption, predation, and exposure to toxins excreted by microorganisms and plants (Díaz et al., 2010). The reduction of hydraulic detention time, due to the increase in the flow rate, influence on the hydraulic regime, potentially leading to short hydraulic circuits and reduced removal efficiency (Jasper et al., 2013; Weerakoon et al., 2013).

From the data compilation presented by Wu et al. (2016), it is possible to verify that the removal of TC in horizontal flow constructed wetland increased from 72.5 to $99.7 \%$ when the hydraulic detention time was increased from 2 to 8 days, while the removal of ThC increased from 63.5 to $99.2 \%$. 
Chagas et al. (2012) managed to remove from domestic sewage treated in CWS, 1 to 4 and 2 to $4 \log$ units of TC and E. coli, respectively. Such removals have been directly associated with the increase of HDT and consequent decrease of organic load rates in the CWS.

According to Calijuri et al. (2009), 2 log units removals of TC and ThC (efficiencies exceeding 99.0\%) were verified in CWS with hydraulic detention time between 4.5 and 5 days. Gonzales et al. (2009) achieved the removal of 3.3 to $4.2 \mathrm{log}$ units in CWS with hydraulic detention time in 3 days used in the treatment of swine wastwwater with $10^{8}$ to $10^{10} \mathrm{MPN}$ $100 \mathrm{~mL}^{-1}$ of total coliforms.

Matos et al. (2009) used a CWS cultivated with Tifton 85 grass, with 4.8 days of hydraulic detention time for treatment of swine wastewater pre-treated in organic filters. An average removal efficiency of $98.3 \%$ of E. coli. was verified. The effluent showed from $10^{4}$ to $10^{7} \times 100 \mathrm{~mL}^{-1} \mathrm{MPN}$ of total coliforms, and from $10^{4}$ to $10^{6} \mathrm{MPN} 100 \mathrm{~mL}^{-1}$ of E. coli, with an average reduction of $2 \log$ units.

In this study, although there are stages subject to different conditions (Stage 1 and Stage 2 ), it was found that higher efficiencies are obtained with the application in vertical-horizontal systems; better performance occurred in vertical systems, as reported by Vymazal (2005) and Haghshenas-Adarmanabadi et al. (2016). In general, the VFCWS associated to HFCWS resulted in efficiencies that ranged from 96.4 to $99.0 \%$ for TC and from 94.2 to $97.6 \%$ to ThC, equal to an average of 2 to $3 \log$ units of removal, considered as satisfactory. Vymazal (2009) reports that the CWS can remove between 1 and $4 \log$ units of ThC. Certifying the efficiency of CWS, Elfanssi et al. (2018) obtained remove over 4 units log in a hybrid constructed wetland system (vertical-horizontal) in domestic effluent treatment.

Observed concentration of coliforms in the effluent in this work remained high, which could restrict the application of treated swine wastewater in fertirrigation, mainly for some plant species. The effluent values recommended by the World Health Organization, depending on the type of crop being irrigated, vary from $10^{3}$ to $10^{6} \times 100 \mathrm{~mL}^{-1} \mathrm{MPN}$ ThC (E. coli) (WHO, 2006). The standard used, less than or equal to $10^{3} \times 100 \mathrm{~mL}^{-1}$ of MPN ThC (ABNT, 1997). It is noted that for unrestricted irrigation a safety margin is applied, more restrictive than World Health Organization guidelines.

Bastos et al. (2008) showed that the irrigation of vegetables that grow low to the ground with effluent from stabilization ponds resulted in acceptable products for consumption, according to the Brazilian legislation criteria for the microbiological quality of food (ANA, 2001). This also was verified with the irrigation of vegetables that grow far from the soil with wastewater containing around $10^{4} 100 \mathrm{~mL}^{-1} \mathrm{MPN}$ of E. Coli.

Bevilacqua et al. (2014) evaluated the health effects on livestock consuming forage fertirrigated by the method of flood and sprinkling system, with biological reactors, whose effluent number of coliforms was greater than recommended by the World Health Organization and found that there was no contamination injurious to health. They stated that this practice did not cause disease (or death) in animals.

Regarding the microbiological analysis of species, coliform contamination has not been verified in Tifton 85 grass (the values obtained in the analysis were equal to zero), although it is believed that the subsurface runoff may contribute by the lack of direct contact of effluent with the aerial parts of the plant.

\section{CONCLUSIONS}

The decrease in hydraulic detention time during the stages reduced coliform removal efficiency.

The increase in organic loads concomitantly with the low temperatures influenced the decrease in coliform removal efficiency. 
Effluent concentration of coliforms remained above the World Health Organization recommendations, however, there was no contamination by coliforms on the shoots of Tifton 85 grass.

The results obtained indicate the necessity of a detailed study of other variables, in order to better understand the removal mechanisms of bacteria coliform groups in constructed wetlands systems.

\section{ACKNOWLEDGMENTS}

The authors gratefully acknowledge Coordination for the Improvement of Higher Education Personnel (CAPES) and Minas Gerais State Research Support Foundation (Fapemig) for the scholarships granted and financial support.

\section{REFERENCES}

ABNT. NBR 13969: Tanques sépticos - Unidades de tratamento complementar e disposição final dos efluentes líquidos - Projeto, construção e operação. Rio de Janeiro, 1997.

ABOU-ELELA, S. I.; HELLAL, M. S. Municipal wastewater treatment using vertical flow constructed wetlands planted with Canna, Phragmites and Cyprus. Ecological Engineering, v. 47, p. 209-213, 2012. https://doi.org/10.1016/j.ecoleng.2012.06.044

AMORIM, F.; FIA, R.; PASQUALIN, P. P.; OLIVEIRA, L. F. C.; SILVA, J. R. M. CapimTifton 85 Cultivado em Sistema Alagado Construído com Elevadas Taxas de Aplicação. Engenharia na Agricultura, v. 23, n. 3, p. 241-250, $2015 \mathrm{a}$. https://dx.doi.org/10.13083/1414-3984/reveng.v23n3p241-250

AMORIM, F.; FIA, R.; SILVA, J. R. M.; CHAVES, C. F. M.; PASQUALIN, P. P. Unidades combinadas RAFA-SAC para tratamento de água residuária de suinocultura. Engenharia Agrícola, v. 35, n. 6, p. 1149-1159, 2015b. http://dx.doi.org/10.1590/1809-4430Eng.Agric.v35n6p1149-1159/2015

AGÊNCIA NACIONAL DE VIGIL NCIA SANITÁRIA (Brasil). Resolução-RDC n ${ }^{\circ}$ 12, de 2 de janeiro de 2001. Aprova o Regulamento Técnico sobre padrões microbiológicos para alimentos. Diário Oficial [da] União: seção 1, Brasília, DF, p. 45-53, 10 jan. 2001.

APHA; AWWA; WEF. Standard Methods for the Examination of Water and Wastewater. 21. ed. Washington, 2005.

BASTOS, R. K. X.; BEVIlACQUA, P. D.; SILVA, C. A. B.; SILVA, C. V. Wastewater irrigation of salad crops: further evidence for the evaluation of the WHO guidelines. Water Science \& Technology, v. 57, n. 8, p. 1213-1219, 2008. https://doi.org/10.2166/wst.2008.244

BEVILACQUA, P. D.; BASTOS, R. K. K.; MARA, D. D. An evaluation of microbial health risks to livestock fed with wastewater-irrigated forage crops. Zoonoses and Public Health, v. 61, n. 4, p. 242-249, 2014. https://doi.org/10.1111/zph.12063

BRASIL, M. S.; MATOS, A. T.; FIA, R.; SILVA, N. C. L. Desempenho agronômico de vegetais cultivados em sistemas alagados utilizados no tratamento de águas residuárias da suinocultura. Engenharia na Agricultura, v. 15, n. 3, p. 307-315, 2007.

BOUTILIER, L.; JAMIESON, R.; GORDON, R.; LAKE, C.; HART, W. Adsorption, sedimentation, and inactivation of $E$. coli within wastewater treatment wetlands. Water Research, v. 43, n. 17, p. 4370-4380, 2009. https://doi.org/10.1016/j.watres.2009.06.039 
CALIJURI, M. L.; BASTOS,R. K. X.; MAGAlHÃES, T. B.; CAPELETE, B. C.; DIAS, E. H. O. Tratamento de esgotos sanitários em sistemas reatores UASB/wetlands construídas de fluxo horizontal: eficiência e estabilidade de remoção de matéria orgânica, sólidos, nutrientes e coliformes. Engenharia Sanitária e Ambiental, v. 14, n. 3, p. 421-430, 2009. http://dx.doi.org/10.1590/S1413-41522009000300016

CAVAlETT, L. E.; LUCCHESI, L. A. C.; MORAES, A; SCHIMIDT, E.; PERONDI, M. A.; FONSECA, R. A. Melhoria da fertilidade do solo decorrentes da adição de água residuária da indústria de enzimas. Revista Brasileira de Engenharia Agrícola e Ambiental, v. 10, n. 3, p. 724-729, 2006. http://dx.doi.org/10.1590/S141543662006000300027

CHAGAS, R. C.; MATOS, A. T.; CECON, P. R.; MÔNACO, P. A. V.; ZAPAROLLI, B. R.; Remoção De Coliformes Em Sistemas Alagados Construídos Cultivados Com Lírio Amarelo (Hemerocallis flava). Engenharia na Agricultura, v. 20, n. 2, p. 142-150, 2012.

CONAMA (Brasil). Resolução n ${ }^{\circ} 430$ de 13 de maio 2011. Dispõe sobre as condições e padrões de lançamento de efluentes, complementa e altera a Resolução no 357, de 17 de março de 2005, do Conselho Nacional do Meio Ambiente-CONAMA. Diário Oficial [da] União: seção 1, Brasília, DF, n. 92, p. 89, 16 maio 2011.

DÍAZ, F. J.; O'GEEN, A. T.; DAHLGREN, R. A. Efficacy of constructed wetlands for removal of bacterial contamination from agricultural return flows. Agricultural Water $\begin{array}{lllllll}\text { Management, } & \text { v. } & 97, \quad \text { n. } & 11, \quad \text { p. } & 1813-1821,\end{array}$ https://doi.org/10.1016/j.agwat.2010.06.015

ELFANSSI, S.; OUAZZANI, N.; LATRACH, L.; HEJJAJ, A.; MANDI, L. Phytoremediation of domestic wastewater using a hybrid constructed wetland in mountainous rural area. International Journal of Phytoremediation, v. 20, n. 1, p. 75-87, 2018. https://doi.org/10.1080/15226514.2017.1337067

FIA, R.; MATOS, A. T.; QUEIROZ, M. E. L. R.; CECON, P. R.; FIA, F. R. L. Desempenho de sistemas alagados no tratamento de águas residuárias do processamento dos frutos do cafeeiro. Revista Brasileira de Engenharia Agrícola e Ambiental, v. 14, n. 12, p. 1323 1329, 2010. http://dx.doi.org/10.1590/S1415-43662010001200011

FIA, R.; VILAS BOAS, R. B.; CAMPOS, A. T.; FIA, F. R. L.; SOUZA, E. G. Removal of nitrogen, phosphorus, copper and zinc from swine breeding wastewater by bermudagrass and cattail in constructed wetland systems. Revista Engenharia Agrícola, v. 34, n. 1, p. 112-113, 2014. http://dx.doi.org/10.1590/S0100-69162014000100013

GONZALEZ, F. T.; VALlEJOS, G. G..; SILVEIRA, J. H.; FRANCO, C. Q.; GARCÍA, J.; PUIGAGUT, J. Treatment of swine wastewater with subsurface-flow constructed wetlands in Yucatan, Mexico: influence of plant species and contact time. Water SA, v. 35, n. 3, p. 335-342, 2009. http://dx.doi.org/10.4314/wsa.v35i3.76778

HAGHSHENAS-ADARMANABADI, A.; HEIDARPOUR, M.; TARKESH-ESFAHANI, S. Evaluation of Horizontal-Vertical Subsurface Hybrid Constructed Wetlands for Tertiary Treatment of Conventional Treatment Facilities Effluents in Developing Countries. Water, Air \& Soil Pollution, v. 227, n. 28, p.1-18, 2016. https://doi.org/10.1007/s11270015-2718-6 
HILL, V. R.; SOBSEY, M. D. Removal of salmonella and microbial indicators in constructed wetlands treating swine wastewater. Water Science Technology, v. 44, n. 11-12, p. 215222, 2001.

JASPER, J. T.; NGUYEN, M. T.; JONES, Z. L.; ISMAIL, N. S.; SEDLAK, D. L.; SHARP, J. O.; LUTHY, R. G.; HORNE, A. J.; NELSON, K. L. Unit Process Wetlands for Removal of Trace Organic Contaminants and Pathogens from Municipal Wastewater Effluents. Environmental Engineering Science, v. 30, n. 8, p.421-436, 2013. https://dx.doi.org/10.1089/ees.2012.0239

KADAM, A. M.; OZA, G. H.; NEMADE, P. D.; SHANKAR, H. S. Pathogen removal from municipal wastewater in constructed soil filter. Ecological Engineering, v. 33, n. 1, p.3744, 2008. https://doi.org/10.1016/j.ecoleng.2007.12.001

KADLEC, R. H.; WALLACE, S. D. Treatment wetlands. $2^{\text {nd }}$ ed. Boca Raton: CRC Press, 2008. 1016p. https://doi.org/10.1201/9781420012514

LIN, Y. F.; JING, S. R.; LEE, D. Y.; CHANG, Y. F.; CHEN, Y. M.; SHIH, K. C. Performance of a constructed wetland treating intensive shrimp aquaculture wastewater under high hydraulic loading rate. Environmental Pollution, v. 134, n. 3, p. 411-421, 2005. https://doi.org/10.1016/j.envpol.2004.09.015

MACHADO, A. I.; BERETTA, M.; FRAGOSO, R.; DUARTE, E. Overview of the state of the art of constructed wetlands for decentralized wastewater management in Brazil. Journal of Environmental Management, v. 187, n. 1, p. 560-570, 2017. https://doi.org/10.1016/j.jenvman.2016.11.015

MATOS, A. T. Disposição de águas residuárias no solo. Viçosa: AEAGRI, 2007. 140p.

MATOS, A. T.; FREITAS, W. S.; FIA, R.; MATOS, M. P. Qualidade do efluente de sistemas alagados construídos utilizados no tratamento de águas residuárias da suinocultura visando seu reuso. Engenharia na Agricultura, v. 17, n.5, p. 383-391, 2009. http://dx.doi.org/10.13083/reveng.v17i5.165

MATOS, A. T.; SILVA, D. F.; MONACO, P. A.; PEREIRA, O. G. Produtividade e composição química do Capim-Tifton 85 submetido a diferentes taxas de aplicação do percolado de resíduo sólido urbano. Engenharia Agrícola, v. 33, n. 1, p. 188-200, 2013. http://dx.doi.org/10.1590/S0100-69162013000100019

MORATÓ, J.: CODONY, F.; SÁNCHEZ, O.; PÉREZ, L. M.; GARCÍA, J.; MAS, J. Key design factors affecting microbial community composition and pathogenic organism removal in horizontal subsurface flow constructed wetlands. Science of The Total Environment, v. 481, p. 81-89, 2014. https://doi.org/10.1016/j.scitotenv.2014.01.068

OLSON, M. R.; AXLER, R. P.; HICKS, R. E. Effects of freezing and storage temperature on MS2 viability. Journal of Virological Methods, v. 122, n. 2, p. 147-152, 2004. https://doi.org/10.1016/j.jviromet.2004.08.010

PEREIRA, O. G.; ROVETTA, R.; RIBEIRO, K. G.; SANTOS, M. E. R.; FONSECA, D. M.; CECON, P. R. Crescimento do capim-tifton 85 sob doses de nitrogênio e alturas de corte. Revista Brasileira de Zootecnia, v. 41, n. 1, p. 30-35, 2012. http://dx.doi.org/10.1590/S1516-35982012000100005

QUEIROZ, F. M.; MATOS, A. T.; PEREIRA, O. G.; OLIVEIRA, R. A.; LEMOS, A. F. Características químicas do solo e absorção de nutrientes por gramíneas em rampas de tratamento de águas residuárias da suinocultura. Engenharia na Agricultura, v. 12, n. 2, p. 77-90, 2004. 
RACHMADI, A. T.; KITAJIMA, M.; PEPPER, I. L.; GERBA, C. P. Enteric and indicator virus removal by surface flow wetlands. Science of The Total Environment, v. 542, part A, p. 976-982, 2016. https://doi.org/10.1016/j.scitotenv.2015.11.001

SANCHES, A. C.; GOMES, E. P.; RICKLI, M. E.; FRISKE, E. Produtividade, composição botânica e valor nutricional do tifton 85 nas diferentes estações do ano sob irrigação. Irriga, Edição Especial - Grandes Culturas, v. 1, n. 1, p. 221-232, 2016. https://doi.org/10.15809/irriga.2016v1n1p221-232

TUNÇSIPER, B.; AYAZ, S. Ç.; AKÇA, L. Coliform bacteria removal from septic wastewater in a pilot-scale combined constructed wetland system. Environmental Engineering $\begin{array}{lllllll}\text { Management Journal, } & \text { v. } 11, \quad \text { n. } & 10, & \text { p.1873-1879, }\end{array}$ https://dx.doi.org/10.30638/eemj.2012.233

VON SPERLING, M. Princípios do tratamento biológico de águas residuárias: introdução à qualidade das águas e ao tratamento de esgotos. 3. ed. Belo Horizonte: Ed. UFMG, 2005.

VYMAZAL, J. Horizontal sub-surface flow and hybrid constructed wetlands systems for wastewater treatment. Ecological Engineering, v. 25, n. 5, p. 478-490, 2005. https://doi.org/10.1016/j.ecoleng.2005.07.010

VYMAZAL, J. The use constructed wetlands with horizontal sub-surface flow for various types of wastewater. Ecological Engineering, v. 35, n. 1, p. 1-17, 2009. https://doi.org/10.1016/j.ecoleng.2008.08.016

WEERAKOON, G. M. P. R.; JINADASA, K. B. S. N.; HERATH, G. B. B.; MOWJOOD, M. I. M.; BRUGGEN, J. J. A. Impact of the hydraulic loading rate on pollutants removal in tropical horizontal subsurface flow constructed wetlands. Ecological Engineering, v. 61, part A, p. 154-160, 2013. https://doi.org/10.1016/j.ecoleng.2013.09.016

WHO. The World Health Report 2006: working together for health. 2006. Available: http://www.who.int/whr/2006/en/ Access: 9 Nov. 2015.

WHO. Drinking-Water. Available: http://www.who.int/mediacentre/factsheets/fs391/en/ Access: 9 Nov. 2015.

WINWARD, G. P.; AVERY, L. M.; FRAZER-WILLIAMS, R.; PIDOU, M.; JEFFREY, P.; STEPHENSON, T.; JEFFERSON, B. A study of the microbial quality of grey water and an evaluation of treatment technologies for reuse. Ecological Engineering, v. 32, n. 2, p.187-197, 2008. https://doi.org/10.1016/j.ecoleng.2007.11.001

WU, S.; CARVAlHO, P. N.; MÜLlER, J. A.; MANOJ, V. R.; DONG, R. Sanitation in constructed wetlands: a review on the removal of human pathogens and fecal indicators. Science of The Total Environment, v. 541, p. 8-22, 2016. https://doi.org/10.1016/j.scitotenv.2015.09.047

ZURITA, F.; CARREON-ÁLVAREZ, A. Performance of three pilot-scale hybrid constructed wetlands for total coliforms and Escherichia coli removal from primary effluent - a 2year study in a subtropical climate. Journal of Water \& Health, v. 13, n. 2, p. 446-458, 2014. https://dx.doi.org/10.2166/wh.2014.135 